\title{
Law Changes and International Standards in the Field of Ecoinnovation
}

\author{
Joanna Witczak \\ PhD, Poznan University of Economics and Business, Department of \\ Commodity Science and Ecology of Industrial Products
}

\section{Introduction}

Ecoinnovations are a fundamental area of activity involving economy, environment and society. They directly and indirectly affect the various fundamental aspects of human activity and, as a result, policy affairs. They are a requirement for increasing competitiveness that can be only reached in a synergic way between economic and ecological effects. Thus ecoinnovation should be based on resource productivity, efficiency, competitiveness and ability to safeguard the environment. It equally concerns profits made directly from decreasing environmental impact as well as social and economic profits arising indirectly. Introduction of ecoinnovation law and international standards is particularly important for creating organisation and consumer pro-ecological behavior. It allows companies to implement and develop more sustainable and eco-conscious solutions.

\section{Ecoinnovations in Poland and EU}

Recent years, mainly due to legislative and organizational changes in European Union, indicate ecoinnovations as a leading area of activity in the field of environmental protection for boosting greening the economy. The Ecoinnovation

How to cite this book chapter:

Witczak, J. 2019. Law Changes and International Standards in the Field of Ecoinnovation. In: Gąsior, A. (ed.) Pro-ecological Restructuring of Companies: Case Studies, Pp. 171-182. London: Ubiquity Press. DOI: https://doi.org/10.5334/bbk.o. License: CC-BY 4.0 
Table 1: Ecoinnovation index in 2010-2015.

\begin{tabular}{|c|c|c|c|c|c|c|}
\hline & 2010 & 2011 & 2012 & 2013 & 2014 & 2015 \\
\hline EU (28) & & & & 100 & 100 & 100 \\
\hline EU (27) & 100 & 100 & 100 & & & \\
\hline Belgium & 114 & 115 & 118 & 101 & 96 & 97 \\
\hline Bulgaria & 58 & 67 & 80 & 38 & 49 & 49 \\
\hline Czechia & 73 & 91 & 90 & 71 & 92 & 99 \\
\hline Denmark & 155 & 138 & 136 & 129 & 185 & 167 \\
\hline Germany & 139 & 123 & 120 & 132 & 134 & 129 \\
\hline Estonia & 56 & 74 & 78 & 72 & 74 & 80 \\
\hline Ireland & 101 & 118 & 113 & 95 & 136 & 134 \\
\hline Greece & 55 & 59 & 67 & 66 & 72 & 72 \\
\hline Spain & 101 & 128 & 118 & 110 & 107 & 106 \\
\hline France & 96 & 99 & 96 & 108 & 112 & 115 \\
\hline Croatia & 0 & 0 & 0 & 57 & 87 & 67 \\
\hline Italy & 98 & 90 & 92 & 95 & 99 & 106 \\
\hline Cyprus & 64 & 71 & 74 & 43 & 59 & 60 \\
\hline Latvia & 60 & 77 & 71 & 52 & 72 & 75 \\
\hline Lithuania & 45 & 52 & 53 & 66 & 71 & 73 \\
\hline Luxemburg & 94 & 130 & 108 & 109 & 188 & 124 \\
\hline Hungary & 70 & 83 & 73 & 61 & 79 & 81 \\
\hline Malta & 66 & 82 & 72 & 67 & 57 & 64 \\
\hline Holland & 110 & 109 & 111 & 91 & 96 & 98 \\
\hline Austria & 131 & 125 & 112 & 106 & 106 & 108 \\
\hline Poland & 54 & 50 & 54 & 42 & 63 & 59 \\
\hline Portugal & 72 & 81 & 84 & 79 & 99 & 102 \\
\hline Romania & 52 & 67 & 78 & 63 & 76 & 82 \\
\hline Slovenia & 75 & 109 & 115 & 74 & 91 & 96 \\
\hline Slovakia & 48 & 52 & 54 & 47 & 68 & 72 \\
\hline Finland & 156 & 149 & 150 & 138 & 135 & 140 \\
\hline Sweden & 128 & 142 & 134 & 138 & 123 & 124 \\
\hline England & 103 & 105 & 101 & 122 & 100 & 106 \\
\hline Iceland & no data & no data & no data & no data & no data & no data \\
\hline Norway & no data & no data & no data & no data & no data & no data \\
\hline Switzerland & no data & no data & no data & no data & no data & no data \\
\hline
\end{tabular}

${ }^{*}$ Index $(\mathrm{EU}=100)$

Source: Eurostat Statistics 2016. 
Index is a rating created on the basis of 16 indicators that depicts the position of each country within the scope of ecoinnovation in relation to the average of the European Union member countries. The number of ecoinnovations implemented in most countries is not high, especially in eastern ones. The Eurostat data show that in the Ecoinnovation Index 2016 Poland belongs to the group of low ecoinnovation (cf. Table 1).

In 2015 Poland has a significantly lower than average (59 out of 100) result in the index, in particular in reference to outlay and activities related to ecoinnovation, which reflects the generally low innovativeness of the country. Poland took the penultimate position ahead of Bulgaria only. This poor result is caused by small outlay linked with ecoinnovation activity, including research and development activity, R\&D personnel, investment at early stages and investment in green technology.

The latest Central Statistical Office data indicate that Polish enterprises introduce not only a low number of ecoinnovations but also little innovation at all (GUS 2015). The number of innovative enterprises in Poland decrease from $27.9 \%$ in 2008 to $23 \%$ in 2012 . The latest GUS data from 2015 indicate that within the group of industrial enterprises, there was a slight increase in the number of innovators. Their share increased from $17.7 \%$ in $2010-2012$ to $18.4 \%$ in 2011-2013. However, in the group of service enterprises the share of innovative companies once again decreased from $13.9 \%$ in $2010-2012$ to $12.8 \%$ in 2011-2013, which is a negative phenomenon as it causes the decrease of the innovative potential. In the case of countries like Poland, this trend creates large risk and may be difficult to reverse.

However, ecoinnovations in 2012-2014 were introduced more often than other process and product innovation. The study showed that in the analyzed years the ecoinnovations were introduced by $10.3 \%$ in industrial and $3.9 \%$ in service enterprises (it refers to both product, process, organisational and marketing innovations). The highest number of implemented innovations were process innovations in industrial enterprises $(4.1 \%)$ and product innovations $(1.7 \%)$ in service enterprises (cf. Figure 1).

The following factors are believed to be key elements of introducing ecoinnovation for companies in Poland: high operational costs, desire to reduce costs related to energy, water and materials, as well as readiness for the access to new market, for increasing competitiveness and improving the reputation of a given company. It is confirmed by the data of Central Statistical Office (GUS 2015), according to which the main factors that amount to the incentive to introduce ecoinnovation in 2012-2014 were (given below according to importance):

- high costs of energy, water and materials;

- improvement of the company's reputation;

- existing legislation related to environmental protection;

- voluntary initiatives for the environment and good practices in the sector;

- existing taxes and environmental fees; 


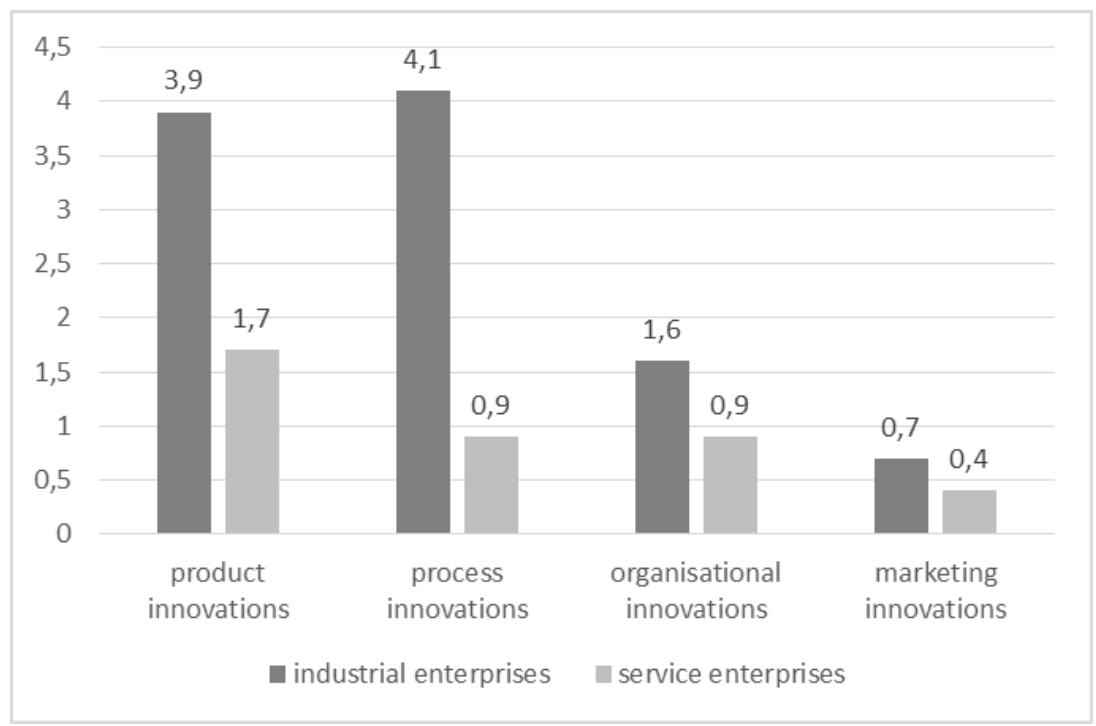

Fig. 1: Polish enterprises which introduced ecoinnovations resulting from types of introduced innovations as the share of total enterprises.

Source: GUS, 2015, Działalność innowacyjna przedsiębiorstw w latach 2012-2014.

- legislation related to environmental protection and expected taxes;

- fashion and expected demand for ecoinnovation;

- meeting requirements within the scope of public tenders; and

- governmental subsidies, subsidies and other financial stimulants for introducing innovation, which is beneficial for the environment (cf. Figure 2).

The importance of the three factors of highest importance is almost the same for industrial and service companies that have introduced ecoinnovation. High costs of energy, water and materials are very important factors for $36.7 \%$ of industrial companies and for $42.3 \%$ of service companies. Existing legislation related to environmental protection is the third most important factor for $19.8 \%$ industrial and $16.9 \%$ service companies. Polish enterprises are aware of environmental regulations or taxes expected in the future and perceive ecoinnovations through the prism of necessity for meeting requirements for public procurement contracts also.

Despite Polish enterprises' awareness of the importance of implementing innovations, private green investment at early stages were one of the lowest in the EU, however, they were at a similar level to other Central and Eastern European countries. Poland is above the EU average in the case of only one indicator - environmental industry income, as a percentage of total income in all companies. Nevertheless, the Polish market of green technologies and 


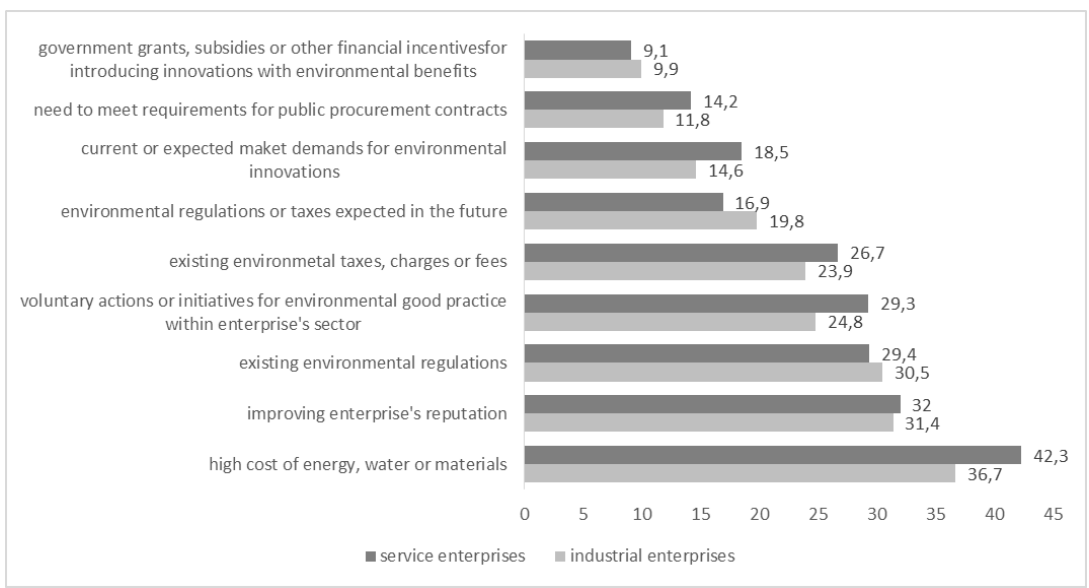

Fig. 2: Polish enterprises that rated importance of a given factor in driving an enterprise's decisions to introduce ecoinnovations as "high" as the share of enterprises which introduced innovations with environmental benefits in the years 2012-2014.

Source: GUS, 2015, Działalność innowacyjna przedsiębiorstw w latach 2012-2014.

ecoinnovation is still at the stage of development and shows its considerable potential for growth (Wrzesiewski \& Miler 2010).

\section{Fostering Ecoinnovation}

Nowadays human beings face a range of environmental challenges that will impact on our future prosperity. These include resource depletion, climate change, increasing water scarcity, air pollution and biodiversity loss. Ecoinnovation and innovative environmental technologies can provide solutions to minimalise environmental impact of our industrial activity. Economic recovery and environmentally and socially sustainable economic growth were recognized as the key challenges for all countries (Declaration on Green Growth 2009). Thus the European Commission puts a lot of effort into supporting ecoinnovation as the most important factor of environmental protection activity.

In 2011 European Commission introduced The Eco-innovation Action Plan (EcoAP). The plan includes targeted actions both on the demand and supply side, on research and industry and on policy and financial instruments. The implementation of the actions will be supported by the partnering approach between stakeholders, private and public sector, and the European Commission. The key EcoAP drivers for the market uptake of ecoinnovation are the following: ${ }^{1}$ 
1) using policies and regulations in the field of environmental protection to promote ecoinnovation

2) supporting demonstration projects and establishing partnerships to introduce promising, smart and ambitious operational technologies to the market

3) developing of new standards to stimulate innovation,

4) mobilizing financial instruments and support services for SMEs

5) promoting international cooperation

6) supporting the development of emerging skills, creating new jobs and training programs for adapting to the labor market needs

7) supporting ecoinnovation through the European Innovation Partnerships foreseen under the "Innovation Union".

For supporting and promoting ecoinnovation the Seventh Environment Action Programme (EcoAP) was introduced. It is a continuation of the ETAP program, which takes a broader approach to the question of ecoinnovation and includes more actions aiming at strengthening stimulants and overcoming barriers to the implementation of original environmentally friendly solutions. EcoAP aims to increase the contribution of environmental policy in the transition to a resource-efficient, low carbon economy in which natural capital is amplified, and the health and welfare of the citizens are protected.

The Seventh Environment Action Programme will be guiding European environment policy until 2020 (including eco-innovation) and concerns the following priority objectives: ${ }^{2}$

(a) to protect, conserve and enhance the Union's natural capital;

(b) to turn the Union into a resource-efficient, green and competitive lowcarbon economy;

(c) to safeguard the Union's citizens from environment-related pressures and risks to health and well-being;

(d) to maximise the benefits of Union environment legislation by improving implementation;

(e) to improve the knowledge and evidence base for Union environment policy;

(f) to secure investment for environment and climate policy and address environmental externalities;

(g) to improve environmental integration and policy coherence;

(h) to enhance the sustainability of the Union's cities;

(i) to increase the Union's effectiveness in addressing international environmental and climate-related challenges.

One of the results of ETAP and EcoAP is creating the Environmental Technology Verification System (EU ETV), which environmentally verifies enterprises in order to eliminate information gaps and market uncertainty related to the 
efficiency of the new environmental solutions. ETV is an initiative which aims to address the problem of credibility of information about the environmental performance of innovative technologies. Environmental Technology Verification (ETV) provides for third-party verification of the performance claims made by technology manufacturers in business-to-business relations.

The European Union has created support instruments focused on innovation and entrepreneurship, which are supposed to develop stimuli for investment in processes and technologies linked with the environment. One of the instruments is the EU Competitiveness and Innovation Program (CIP). It is used to propagate ecoinnovation in the form of various support actions, e.g. risk capital funding and actions for the development of the cooperation network.

The LIFE program is dedicated uniquely to co-funding projects within the scope of environmental and climate protection. It is a financial instrument of the European Union, which follows the LIFE+ program. Its main aim is to support the process of implementing the community environmental protection law, the realization of the EU policy within this scope, as well as the identification and promotion of new solutions for environmental problems.

In 2014-2020 the financial instrument of the "Innovation Union" project is the EU program for scientific research and innovation - "Horizon 2020". Its objective is to support research within the scope of new solutions, as well as the monitoring, presentation and market development of them.

In Poland a number of initiatives have been undertaken aimed at popularizing the knowledge of ecoinnovation. One of the projects focused on this objective is the national information and educational campaign entitled "Are you a creator? Become an ecoinnovator!" conducted in 2014-2015 by the University of Economics in Poznań, which in order to realize this undertaking, obtained funding from the National Fund for Environmental Protection and Water Management. The project was dedicated to widespreading information and knowledge about ecoinnovation among different target groups (entrepreneurs, administration, researchers, students). All tasks realized within the project and its results can be accessed at www.ekoinnowator.ue.poznan.pl.

The first Polish industrial program in the area of environmental actions is Gekon (Environmental Conception Generator). It was prepared and realized by two institutions: the National Research and Development Center and the National Fund for Environmental Protection and Water Management. The program supports projects from the private sector related to conducting scientific research and development, and then implementing the obtained results in the form of innovative environmental technologies.

A national support instrument is also the program of the Ministry of the Environment called GreenEvo - an accelerator of green technologies (Polish abbreviation: AZT). The initiative aims at helping Polish ecoinnovators to enter the global market. The help is realized in the organizational, technical and financial aspects. 


\section{Environmental Legislation}

As one of the basic supporting instruments, environmental legislation is very important driver for ecoinnovation and for the industry development. The main areas involving are water and air pollution, waste management, recycling, and climate change mitigation. There are a number of regulations dealing directly or indirectly with ecoinnovations. In the area of Environment, Health and Safety, roughly 500 additional regulations were adopted in 2012 compared to 2009 (Shaffer \&Hendel-Blackford 2013). Many of them have been a strong driver for ecoinnovation in a variety of sectors.

The REACH (Registration, Evaluation, Authorization \& Restriction of Chemicals) ${ }^{3}$ regulation is dedicated to chemical companies. It covers lists of substances of very high concern (SVHC) for which substitution is required when safer alternative substances or technologies become technically and economically feasible. The REACH validity forces an active search for more environmental friendly and safer substitutes as well as stimulates R\&D activities. The regulation is also a very good example of driving innovation worldwide. On the one hand the chemical companies across the world must follow the REACH when developing products that should meet the requirements of EU markets. Inside the EU, the regulation affects a wide range of producers, importers and exporters across many sectors and impacts a variety of goods from chemical components to finished products.

Product-focused environmental regulation is also the WEEE (Waste Electrical and Electronic Equipment) Directive. ${ }^{4}$ It shifts the responsibility of the post-use phase to the producer. The first WEEE Directive (Directive 2002/96/ EC) entered into force in February 2003. The directive provided for the creation of collection schemes where consumers return their WEEE free of charge. These schemes aim to increase the recycling of WEEE and/or re-use. The directive was revised in December 2008 in order to tackle the fast-increasing waste stream. The new WEEE Directive 2012/19/EU entered into force on 13 August 2012 and became effective on 14 February 2014. The directive related to electronic products is also Directive 2009/125/EC of the European Parliament and of the Council of 21 October 2009 establishing a framework for the setting of ecodesign requirements for energy-related products.

The RoHS (Restriction of the use of Hazardous Substances) Directive ${ }^{5}$ restricts the use of certain substances in products. RoHS Directive 2002/95/EC entered into force in February 2003. The legislation requires heavy metals such as lead, mercury, cadmium, and hexavalent chromium and flame retardants such as polybrominated biphenyls (PBB) or polybrominated diphenyl ethers (PBDE) to be substituted by safer alternatives. In December 2008, the revision was done and the RoHS recast Directive 2011/65/EU was introduced on 3 January 2013.

The environmental issues are also present in ISO 14000 standards. The most important are these referring to ecodesign and life cycle assessment mentioned below: 
- ISO 14001: Environmental management systems. Requirements with guidance for use. ISO 14004: Environmental management systems - General guidelines on principles, systems and support techniques.

- ISO 14030s: Environmental management - Environmental performance evaluation.

- ISO 14040s: Environmental management - Life Cycle Assessment.

- ISO 14020s: Environmental labels and declarations.

- ISO/TS 14067: Greenhouse gases - Carbon footprint of products -Requirements and guidelines for quantification and communication.

- ISO 14046: Environmental management. Water footprint - principles, requirements and guidelines (under construction).

- ISO/TR 14062 (2002): Environmental management - Integrating environmental aspects into product design and development.

- ISO 14006 (2011): Environmental management systems - Guidelines for incorporating eco-design.

The mentioned standards specify principles, requirements and guidelines related to products, processes and organisations based on life cycle assessment (LCA). They give the information and the structure of general LCA or design procedure and are dedicated for including the environmental aspects into whole life cycle.

The European Commission has taken actions aiming at supporting the green product market. In the communication to the European Parliament, the Council, the European Economic and Social Committee, and the Committee of the Regions "The Roadmap to a Resource Efficient Europe" the Commission obliged itself to establish a methodological approach, which will enable a thorough evaluation, presentation and comparative analysis of products, services and enterprises on the basis of the comprehensive evaluation of environmental efficiency throughout life. As a result of actions taken in 2013, the European Commission issued a recommendation on the use of common methods to measure and communicate the life cycle environmental performance of products and organizations (2013/179/EU). The aim of these actions is the development of a common methodology for qualitative evaluation of products' environmental impact in their whole life cycle as a way of supporting the credibility of the evaluation and labelling. The European Commission recommendations are not binding for member states nowadays. However, the methodology in the future may become a part of obligatory legislation within the scope of environmental protection, energy efficiency, green public tenders and other disciplines contributing to strengthening the competitiveness of green economy.

Nowadays the European Commission's strategy is to introduce and implement the conception of a "circular economy" into practice. It is based on a recycling society with the aim of reducing waste generation and using waste as a resource. It provides also life cycle thinking to achieve more efficient and 
more sustainable products and services. In 2015 the EU action plan for the Circular Economy ${ }^{6}$ was introduced. The plan establishes a concrete programme of action, with measures covering the whole cycle, from production and consumption to waste management and the market for secondary raw materials. The proposed actions aim to "close the loop", which means recycling and re-use in product lifecycles.

\section{Conclusions}

Ecoinnovation is a combination of innovative solutions and the care of the environment. It is an essential part of the sustainable economy. Ecoinnovation provides opportunities for development and promotion, long-term welfare, as well as maintaining competitiveness. It calls for investment in both scientific research and human capital. Thus, the necessity of creating proper conditions for the green economic growth is very high. It means development favorable for entrepreneurs dealing with the implementation of environmental friendly scenarios. However, appropriate actions must be taken for creating and popularizing environmental behaviors and habits also. Therefore, it seems that launching various types of initiatives leading to increasing the knowledge of ecoinnovation, presenting concrete examples and solutions combined with legal actions may become a stimulus for the innovativeness growth. It creates the need for an ecoinnovation implementation strategy in enterprises. The right direction of future changes seems to be the environmental impact evaluation that may contribute to protect the environment as well as increase the economy's competitiveness. The main issue of introducing environmental legislation is bringing benefits for both the environment and the economy. International standards obligatory in all countries are one of the main factors contributing to improving producers' and consumers' practices to make environmental change in the way they think, to introduce the life cycle thinking.

\section{Notes}

${ }^{1}$ Communication from the Commission to the European Parliament, the Council, the European Economic and Social Committee and the Committee of the Regions, Innovation for a sustainable Future - The Eco-innovation Action Plan (Eco-AP), Brussels, 15.12.2011, COM(2011) 899 final.

${ }^{2}$ Decision No 1386/2013/EU of the European Parliament and of the Council of 20 November 2013 on a General Union Environment Action Programme to 2020 'Living well, within the limits of our planet.

${ }^{3}$ Regulation (EC) No 1907/2006 of the European Parliament and the Council on the Registration, Evaluation, Authorisation and Restriction of Chemicals (REACH). 
${ }^{4}$ Directive 2012/19/EU of the European Parliament and of the Council of 4 July 2012 on waste electrical and electronic equipment (WEEE).

${ }^{5}$ Directive 2011/65/EU of the European Parliament and of the Council of 8 June 2011 on the restriction of the use of certain hazardous substances in electrical and electronic equipment.

${ }^{6}$ Communication from the Commission to the European Parliament, the Council, the European Economic and Social Committee and the Committee of the Regions, Closing the loop - An EU action plan for the Circular Economy, 2.12.2015, Brussels, COM/2015/0614 final.

\section{References}

Communication from the Commission to the European Parliament, the Council, the European Economic and Social Committee and the Committee of the Regions, A resource-efficient Europe - Flagship initiative under the Europe 2020 Strategy, Brussels, 26.1.2011, COM (2011) 21.

Communication from the Commission, Europe 2020. A strategy for smart, sustainable and inclusive growth, 3.3.2010, Brussels, COM (2010) 2020 final.

Communication from the Commission to the European Parliament, the Council, the European Economic and Social Committee and the Committee of the Regions, Innovation for a sustainable Future - The Eco-innovation Action Plan (EcoAP), Brussels, 15.12.2011, COM (2011) 899 final.

Communication from the Commission to the European Parliament, the Council, the European Economic and Social Committee and the Committee of the Regions, Roadmap to a Resource Efficient Europe, 20.9.2011, Brussels, COM (2011) 571 final.

Communication from the Commission to the European Parliament, the Council, the European Economic and Social Committee and the Committee of the Regions, Closing the loop - An EU action plan for the Circular Economy, 2.12.2015, Brussels, COM/2015/0614 final.

COM (2010) 2020, EUROPE 2020 A strategy for smart, sustainable and inclusive growth.

Decision No 1386/2013/EU of the European Parliament and of the Council of 20 November 2013 on a General Union Environment Action Programme to 2020 'Living well, within the limits of our planet.'

Declaration on Green Growth, adopted at the Meeting of the Council at Ministerial Level on 25 June 2009, C/MIN (2009)5/ADD1/FINAL.

Directive 2012/19/EU of the European Parliament and of the Council of 4 July 2012 on waste electrical and electronic equipment (WEEE).

Directive 2011/65/EU of the European Parliament and of the Council of 8 June 2011 on the restriction of the use of certain hazardous substances in electrical and electronic equipment.

Eurostat Statistics 2016. 
Foltynowicz, Z 2009 Ekoinnowacje szansą na rozwój”, Ecomanager nr 1 (in Polish).

GUS 2015 Działalność innowacyjna przedsiębiorstw w latach 2012-2014 (in Polish).

Innovation for a sustainable Future - The Eco-innovation Action Plan (EcoAP), European Commission, COM(2011) 899, Brussels 15.12.2011.

Regulation (EC) No 1907/2006 of the European Parliament and the Council on the Registration, Evaluation, Authorisation and Restriction of Chemicals (REACH).

Towards Green Growth, 2011, OECD.

Shaffer, V and Hendel-Blackford, T 2013 Then and Now: The Difference 4 Years Can Make in EHS Regulatory Focus around the World. 29 March 2013. www.ehstoday.com/safety/then-and-now-difference-4-years-can-makeehs-regulatory-focus-around-world-slideshow

UNEP 2014, The Business Case for Eco-innovation.

Witczak, J (ed.) 2014 Jesteś kreatorem? Zostań innowatorem!, dodatek do Przeglądu Komunalnego 7/2014 Available at http://ekoinnowator. ue.poznan.pl/files/Biuletyn_nr_1.pdf (in Polish).

Wrzesiewski, T and Miler, R 2010, Polski Rynek Technologii Środowiskowych, Warszawa (in Polish). 